\title{
KONSEP KURIKULUM PENDIDIKAN ISLAM MENURUT MUHAMMAD NATSIR
}

\author{
Edy Saputra \\ Sekolah Tinggi Agama Islam Negeri Teungku Dirundeng Meulaboh \\ Email: edysaputra@staindirundeng.ac.id
}

\begin{abstract}
Abstrak
Artikel ini mengkaji konsep kurikulum pendidikan Islam menurut Muhamamd Natsir. Kajian ini termasuk katagori penelitian kepustakaan. Metode kajian yang digunakan adalah deskriftif analitis. Data primer dalam kajian ini berasal dari buku Capita Selecta karya Muhammad Natsir. Hasil dari kajian ini menunjukkan bahwa Muhamamd Natsir telah melakukan reformasi kurikulum pada masanya. Kurikulum yang ditawarkan Muhammad Natsir adalah kurikulum integral yang mengintegrasi pendidikan agama dan umum sebagai sintesis dari kurikulum pendidikan Islam yang dikotomi yang berlaku saat itu.
\end{abstract}

Kata kunci: Muhammad Natsir, Kurikulum, Pendidikan Islam.

\begin{abstract}
This article examines the concept of the Islamic education curriculum according to Muhammad Natsir. This study is included in the library research category. The study method used is descriptive-analytical. The primary data in this study came from the book Capita Selecta by Muhammad Natsir. The results of this study indicate that Muhamamd Natsir has made curriculum reforms during his time. The curriculum offered by Muhammad Natsir is an integrated curriculum that integrates religious and general education as the synthesis of the current dichotomy of the Islamic education curriculum.
\end{abstract}

Keywords: Muhammad Natsir, Curriculum, Islamic Education. 


\section{A. PENDAHULUAN}

Salah satu komponen yang sangat berpengaruh dalam sistem pendidikan adalah kurikulum. Desain sebuah kurikulum sangat menentukan tercapai atau tidak tujuan pendidikan yang di harapkan dan sekaligus sebagai pedoman dalam pelaksanaan pendidikan pada setiap level dan tempat. Istilah kurikulum pertama kali muncul di skotlandia sekitar tahun 1829, namun secara resmi istilah itu baru digunakan hampir satu abad kemudian di Amerika Serikat (Ansyar, 2015: 24). Sumber lain mengatakan, bahwa istilah kurikulum pertama kali muncul dalam kamus Webster tahun 1856 (Tafsir, 2014:53). Secara bahasa istilah kurikulum berasal dari bahasa Yunani, yaitu curir yang artinya pelari dan curare yang berati tempat berpacu (Ramayulis, 2013:230). Jadi, kurikulum pada dasarnya berasal dari dunia olah raga di Yunani kuno yang mempunya arti jarak yang harus ditempuh oleh seorang pelari dari garis start sampai finish.

Dari beberapa referensi yang penulis telusuri, para ahli tidak memiliki kesepakan dalam pendefinisian kurikulum. Para ahli telah mendefinisikan kurikulum pendidikan dalam beberapa definisi. Mulai dari definisi tradisional yang menyatakan kurilulum adalah seluruh pelajaran yang disampaikan guru dan harus ditempuh oleh peserta didik untuk memperoleh ijazah, hingga definisi dalam pandangan modern yang mendefinisikan kurikulum segala sesuatu yang nyata terjadi dalam proses pendidikan atau disebut pengalaman belajar. Namun, definisi yang paling popular ialah kurikulum sebagai rancangan (plan) untuk mencapai tujuan pendidikan (Nizar dan Ramayulis, 2011: 192-194; Ramayulis, 2013: 230-233; Tafsir, 2014: 53-54; Ansyar, 2015: 2426; Syaodih Sukmadinata, 2017: 4).

Mohammad Ansyar (2015: 23-42) menghimpun beberapa defenisi kurikulum yang berkembang, diantaranya: (1) kurikulum sebagai rencana pembelajaran untuk mencapai tujuan pendidikan, (2) kurikulum sebagai mata pelajaran, (3) kurikulum sebagai konten atau materi pelajaran, (4) kurikulum sebagai hasil belajar, (5) kurikulum sebagai reproduksi social, (6) kurikulum sebagai pengalaman belajar, (7) kurikulum sebagai sistem produksi, dan (8) kurikulum sebagai bidang studi.

Dari beberapa definisi yang dihimpun Muhammad Ansyar (2015: 23- 42), penulis menilai terjadi perbedaan para pakar dalam pendefinisian kurikulum adalah hal yang sangat wajar. Mengingat kurikulum sendiri bersifat dinamis dan selalu berubah-rubah sesuai dengan tempat dan waktu serta sudut pandang yang digunakan oleh para ahli dalam pendefinisian. Sifat kurikulum yang dinamis menyebabkan tidak ada definisi kurikulum universal yang disepakaiti bersama. Bahkan, didalam sebuah Negara, kurikulum selalu berubah-rubah disebabkan berbagai factor. Perubahan politik suatu Negara, tidak jarang mempengaruhi kurikulum pendidikan di Negara tersebut. Pada masa orde lama kurikulum pendidikan di Indonesia berorientasi kearah komunisme, sekolah-sekolah di dikembangkan dokrin komunis yang dikemas dengan Kurikulum Bingkai Pendidikan Nasional yang disebut "Sistem Pendidikan Wardhana", atau pada masa orde baru kurikulum beorientasi kearah Pancasilais yang menjadikan pelajaran PMP sebagai pelajaran wajib pada setiap jenjang pendidikan (Nizar dan Ramayulis, 2011: 199).

Indonesia sebagai sebuah bangsa yang memiliki nilai-nilai kebudayaan dan agama memiliki pengertian tersendiri terhadap kurikulum pendidikan. Pengertian tersebut dijadikan sebagai standar untuk mencapai tujuan pendidikan yang dilaksanakan. Menurut UU Sistem Pendidikan Nasional (UU SISDIKNAS) Nomor 20/2003, kurikulum adalah seperangkat rencana dan pengaturan mengenai tujuan, isi, dan bahan pelajaran serta cara yang digunakan sebagai 
pedoman penyelenggaraan kegiatan pembelajaran untuk mencapai tujuan pendidikan tertentu. Dari pengertian tersebut, ada empat komponen terbentuknya sebuah kurikulum yang berkaitan satu dengan yang lainnya, yaitu tujuan, materi, metode, dan evaluasi. Keempat komponen pembentukan kurikulum tersebut sesuai dengan yang dirumuskan oleh para pakar pendidikan, walaupun sebagian pakar menambah beberapa komponen lainnya, seperti organisasi kurikulum dan stategi, tetapi menurut penulis, dua tambahan ini tidak tertalu esensial dan sudah menjadi bagian dari keempat komponen sebelumnya (Ramayulis dan Nizar, 2011:191-192; Ramayulis, 3013:234-236; tafsir, 2014:54).

Kurikulum seringkali dijadikan sebagai factor utama penurunan mutu pendidikan. Misalnya, kurikulum dianggap terlalu dikotomi antara pendidikan umum dan agama. Dikotomi kurikulum merupakan tantangan tersendiri bagi pendidikan Islam. Adanya label ilmu dunia dengan ilmu agama yang saling menafikan, hingga beberapa istilah yang kurang tepatpun muncul, misalnya fakultas agama Islam dan fakultas umum, madrasah dan sekolah.

Dikotomi ini bahkan memunculkan satu fenomena yang sangat disayangkan, yaitu tumbuh pemahaman dan pemikiran sebagian orang yang mengaku sebagai "orang umum". Orang umum yang tidak ingin dikaitkan dengan ilmu agama dan tidak ingin pengaruhi oleh agama. Paradigma yang dikhotomi tesebut seperti berupaya "membunuh" sisi spiritualitas wahyu dalam pendidikan. Akhirnya, muncul anggapan sebagian masyarakat yang mengatakan bahwa ilmu agama dan ilmu umum merupakan dua entitas yang tidak bisa dipertemukan (Tholkhah dan Barizi, 2004: 24). Ini masalah yang sangat krusial. Sebab itu, diperlukan gagasan-gagasan yang dapat menyelesaikan masalah ini.

Dalam cacatan sejarah bangsa ini, ternyata sangat banyak para tokoh pelaku sejarah yang telah memberikan kontribusi berupa gagasan-gagasan cemerlang tentang pendidikan. Oleh sebab itu, penulis melihat sangat penting untuk dikaji pemikiran para tokoh bangsa pelaku sejarah sebagai upaya mengali dan menjaga warisan intelektual yang pernah mengendalikan perjalanan sejarah bangsa. Minimal gagasan tersebut bisa dijadikan sebagai solusi terhadap masalah diatas.

Dalam studi histiografi, paling tidak ada lima yang mengendalikan perjalanan sejarah, yaitu: (1) para dewa, (2) rencana besar tuhan, (3) gagasan-gagasan besar yang pernah dilahirkan anak manusia, (4) tokoh-tokoh besar, serta (5) keadaan social ekonomi. Dua dari lima pengendali sejarah ternyata menyangkut tokoh, yaitu tokoh-tokoh besar dan gagasan-gagasannya. Oleh karena itu, kajian tentang pemikiran tokoh sangat penting disetiap masa untuk setiap bangsa didunia ini (Harahap, 2011: 4).

Kajian pemikiran seorang tokoh memang sangat relevan untuk dikaji pada zaman sekarang, relevansi ini paling tidak bisa dilihat dari tiga hal. Pertama, sifatnya yang sangat menarik bagi manusia sebagai cara untuk mengetahui perkembangan sejarahnya; kedua, studi tokoh juga dapat dijadikan sebagai tempat berpijak untuk memulai gagasan yang lebih besar dimasa depan dari apa yang pernah dipikirkan dan digagaskan oleh tokoh-tokoh terdahulu; ketiga, sebagai seleksi validitas perkembangan berbagai pertemuan (Harahap, 2011: 4).

Ketokohan seseorang bisa kita lihat dari tiga indikator. Pertama, integritas tokoh tersebut. Hal ini setidaknya dapat dilihat kedalaman ilmu dan kepemimpinannya. Kedua, karyakarya monumental yang pernah ditulis oleh tokoh tersebut. Ketiga, kontribusi dan pengaruhnya terlihat atau dirasakan secara nyata oleh masyarakat, baik dalm bentuk pikiran maupun keteladanan hingga ketokohannya diidolakan, diakui serta diteladanin dan dianggap memberikan 
inspirasi bagi generasi sesudahnya. Dari tiga indikator ketokohan seseorang tersebut, Muhammad Natsir memenuhi ketiga indikator diatas untuk diteliti pemikirannya. Tokoh yang dikenal sebagai seorang birokrat, Cendekiawan, pejuang, politisi, ulama dan da'i, sekaligus negarawan Islam ternama yang memiliki karya tulis yang sangat banyak (Harahap, 2011: 4; AlAsy'ari, 2014: 458: Sukri, 2019: 82).

Ketokohan Muhammad Natsir sering kali hanya dibatasi pada gerakan politik dan dakwah beliau di Masyumi atau DDII. Namun, sebagai seorang tokoh pendidikan, Muhammad natsir sering dilupakan. Padahal Muhammat Natsir salah satu tokoh bangsa telah memberikan kontribusi berupa gagasan-gagasan tentang pendidikan. Natsir telah melakukan reformasi (Tajdid) kurikulum pendidikan Islam yang berbasis Alquran dan Sunnah. Natsir melihat bahwa masalah pokok untuk mengatasi keterbelakangan dalam pendidikan dengan merombak sistem dan kurikulum yang dikotomis. Selanjutnya, dia menawarkan konsep kurikulum yang terintegrasi antara pendidikan agama dan umum. Oleh sebab itu, kajian tentang pemikiran Natsir tentang pendidikan, secara khusus kurikulum, merupakan studi yang amat menarik dan penting untuk diteliti serta cukup beralasan.

Berdasarkan latar belakang masalah diatas, penulis akan mengkaji dan menganalisa secara mendalam tentang reformasi kurikulum pendidikan Islam yang dilakukan Natsir. Kajian ini dengan mengangkat judul jurnal yaitu: “Konsep Kurikulum Pendidikan Menurut Muhammad Natsir".

\section{B. METODE PENELITIAN}

Penelitian ini termasuk katagori penelitian kepustakaan (library research) karena data yang diteliti bersumber dari naskah atau buku-buku dari khazanah kepustakaan. Selain referensi yang sudah tercetak, karya-karya non cetak yang yang tersimpan dalam media elektronik juga dijadikan sumber data dalam penelitian kepustakaan ini (Harahap, 2014: 68-74; Nazir, 1985: 25; Khatibah, 2011: 36-39).

Sumber data yang digunakan dalam penelitian ini bersumber dari sumber data primer dan sekunder. Sumber primer dalam penelitian ini yang dijadikan rujukan utama oleh penulis dari karya fenomenal Muhammad Natsir, yaitu: Capita Selecta (Jakarta: Bulan Bintang, 1973). Adapun sumber Sekunder berupa beberapa penelitian yang relevan dengan substansi penelitian ini. Semua sumber yang dikutip akan disebutkan dalam daftar referensi.

Semua ayat Alquran yang digunakan dalam penelitian ini diambil dari program komputer Qur'an Kemenag In MS. Word. Program ini dikembangkan oleh Lajnah Pentashihan Mushaf Al-Qur'an (LPMQ) sebagai satuan kerja di bawah Badan Litbang dan Diklat Kementerian Agama. Program ini dapat diunduh di https://ajnah.kemenag.go.id/unduhan/category/1-qkiw.

Metode penelitian yang digunakan adalah metode deskriptif analitis atau disebut metode analitis kritis. Metode ini merupakan hasil pengembangan dari metode deskriptif yang digagaskan oleh Jujun S. Suriasumantri (1998: 41-61) sebagai paradigma kebersamaan dalam tulisannya "Penelitian Ilmiah, Kefilsafatan, dan Keagamaan: Mencari Paradigma Kebersamaan". Adapun langkah-langkahnya adalah sebagai berikut:

1. Mengumpulkan data-data dari berbagai sumber, baik sumber primer maupun sekunder yang terkait dengan tema penelitian. 
2. Melakukan identifikasi wacana terkait judul dan masalah penelitian dari sumber primer maupun sekunder.

3. Membaca, menelaah, menganalisis, dan mengintepretasi data penelitian yang sudah dikumpulkan terkait dengan teman penelitian serta melakukan pencocokan dan perbandingan antara berbagai data yang ada.

\section{HASIL DAN PEMBAHASAN}

\section{Biografi Singkat Muhammad Natsir}

Muhammad Natsir anak dari pasangan Idris Sutan Saripado dan Khadijah yang dilahirkan pada 17 Juli 1908 di Alahan Panjang, Tanah Minangkabau, Sumatera Barat. Masa kecil Natsir tumbuh dalam kondisi yang penuh dengan gejolak sosial keagamaan. Minangkabau saat itu merupakan basis utama gerakan kaum pembaharuan Islam yang dipelopori kaum Padri. Gerakan pembaharuan ini mengakibatkan perdebatan intelektual dengan kaum adat, Natsir melihat dan bahkan ikut bagian dalam dinamika itu. Dalam asuhan orang tua, guru, dan keterlibatan dalam dinamika sosial keagamaan tersebut, Natsir telah bersentuhan dengan Islam modernis sejak kecil (Roziqin, dkk, 2009:221; Rajab, 2016:104; Sumanto, 2016: 88).

Natsir kecil selain belajar agama di surau, dia mendapatkan pendidikan formal di Sekolah Rakyat (SR). Sekolah rendahan yang memisahkan kalangan masyarakat miskin dan bangsawan. Disinilah Natsir mengenyam pendidikannya hingga kelas dua. Natsir kembali harus pindah belajar ke Hollandsch Inlandsche School (HIS) Adabiyah Padang dan tinggal bersama pamannya, Ibrahim. Saat itu, HIS Adabiyah padang menyelenggarakan pendidikan yang mengacu pada kurikulum Belanda, namun dilengkapi dengan keislaman (Roziqin, dkk, 2009:221).

Saat belum selesai dikelas satu, Natsir kembali harus pindah sekolah ke Solok. Kota Solok saat itu memiliki sekolah HIS kepunyaan Pemerintah yang baru saja diresmikan. Natsir pun didaftarkan oleh bapaknya ke sekolah tersebut. Disini, Natsir kembali mendapatkan promosi karena kepintarannya untuk langsung duduk dikelas dua. Disekolah inilah awal mula Natsir berinteraksi dengan sistem pendidikan modern ala kolonial saat itu (Roziqin, dkk, 2009:221).

Di Solok, Natsir menjalani dua proses pendidikan di dua tempat berbeda. Setiap pagi Natsir belajar pendidikan modern di HIS milik pemerintah. Sedangkan di sore hari, Natsir memperdalam ilmi agama di Madrasah Diniyah yang dipimpin oleh salah seorang pengikut Haji Rasul, yaitu Tuanku Mudo Amin. Disini Natsir kembali tidak bisa terlalu lama belajar. Saat duduk di kelas empat, atas ajakan kakanya, Natsir kembali harus pindah sekolah ke Padang dan diterima dikelas lima HIS Padang. Di HIS Padang inilah Natsir dapat menyelesaikan pendidikannya dengan nilai sangat memuaskan.

Sebagai lulusan HIS Padang dengan nilai yang sangat memuaskan, Natsir diberikan beasiswa untuk meneruskan pendidikan ke tingkat Meer Uitgebreid Lager Onderwijs (MULO) milik pemerintah Belanda di kota Padang. Dimasa itu setiap pelajar yang belajar di MULO adalah pelajar terpandang dan brilian (Syam, 2004:119). Natsir belajar disekolah ini antara tahun 1923-1927. Masa itu, Natsir sempat terlibat sebagai anggota dalam perkumpulan Jong Islamieten Bond (JIB) yang dipimpin Sanusi Pane, seorang tokoh Islam dan sastrawan terkenal saat itu. Di JIB inilah Natsir memanfaatkan masa mudanya untuk terus belajar dan menempa dirinya agar 
tumbuh kesadaran serta semangat untuk memperjuangkan nasib bangsanya (Roziqin, dkk, 2009:221).

Di MULO, Natsir kembali menyelesaikan pendidikannya dengan nilai yang sangat baik. Atas dasar itu, pemerintah kembali memberi Natsir beasiswa penuh untuk jenjang SMA di Algemen Midlebare School (AMS) di kota Bandung. Di Bandung Natsir pertama kali berjumpa dan berinteraksi dengan tokoh modernis A. Hasan. Selanjutnya Natsir belajar secara mendalam ajaran Islam dibawah bimbingan A.Hasan. Bisa dikatakah bahwa A.Hasan merupakan tokoh utama yang mewarnai pemikiran keagamaan Natsir. Selain A. Hasan, H.Agus Salim dan Syaikh Ahmad Surkati juga secara Interaktif mempengaruhi pemikirannya. Natsir pernah bercerita tentang tokoh-tokoh yang berhasil mempengaruhi pemikirannya: " Pertama, guru saya dalam bidang keagamaan adalah Ahmad Hasan,... kedua dalam bidang politik, saya banyak diilhami oleh H.Agus Salim,... dan Ketiga ialah Syaikh Ahmad Sukarti” (Pratikya, 1989:26).

Saat sekolah di AMS Bandung, Natsir kembali aktif di JIB Bandung. Sebab kepiawaianya dalam berorganisasi, Natsir dipilih sebagai ketua prganisasi tersebut antara tahun 1928-1932. Setelah tamat dari AMS Bandung, Natsir kembali mendapatkan tawaran beasiswa belajar di sebuah Fakultas Ekonomi di Belanda. Melihat kondisi bangsanya yang sedang dijajah saat itu, tawaran beasiswa tersebut ditolak oleh Natsir. Pesan gurunya sekaligus kepala sekolah AMS, Dr.Van Bessem selalu teringat ditelingannya: "Sebagai segelintir orang terdidik, kamu harus memerdekankan bangsamu" (Windi, 2007:138). Pesan ini menjadi motivasi baginya untuk tetap memperjuangkan kemerdekaan bangsa. Salah satu bentuk perjuangan Natsir adalah lewat jalur pendidikan. Natsir akhirnya menolak melanjutkan pendidikan ke Belanda. Natsir memilih untuk belajar dan bekerja di malah Pembela Islam milik Persis yang diasuh oleh gurunya, A. Hasan. Selang beberapa tahun, Natsir mendalami ilmu pendidikan di Lager Onderwijs (LO) selama setahun, antara 1931-1932. Selanjutnya, Natsir mendirikan sebuah lembaga pendidikan Islam yang dikenal dengan nama Pendidikan Islam (PENDIS). Pendis sempat berjalan beberapa tahun sebelum ditutup oleh Belanda pada tahun 1941 (Nata, 2005:76).

Pendis yang dipimpin oleh Natsir merupakan cikal bakal Universitas Islam Bandung (UNISBA). Pendis adalah lembaga pendidikan dengan kurikulum yang integral dari tingkat dasar hingga tingkat atas. Natsir memipin Pendis selama sepuluh tahun dari 1032-1942. Di Pendis, Natsir merealisasikan semua ide-ide pendidikan yang dikampanyekannya (Falah, 2015:1092; Suwarno, 2017:94). Pelajaran agama dan umum disejajarkan, kedua bidang ilmu tersebut di berikan porsi yang cukup di Pendis. Selain kurikulum yang Integral di Pendis, Natsir tidak menjadikan Pendis sebagai satu-satunya lembaga pendidikan yang dijadikan sebagai model saat itu. Bahkan, atas inisiatif gurunya A. Hassan, tahun 1936 Natsir juga membantu mendirikan Pesantren Persatuan Islam (PERSIS).

Sebagai seorang ilmuan dan ulama, Natsir banyak menuangkan pemikirannya dalam bentuk tulisan. Diantaranya (Rajab, 2016:109):

a. Islam Sebagai Ideologi yang terbit di Jakarta tahun 1951.

b. Agama dan Negara, Falsafah Perjuangan Islam yang diterbitkandi medan tahun 1951.

c. Capita Selekta yang merupakan sumber data utama dalam penelitian ini.

d. The New Morality terbit tahun 1969 di Surabaya.

e. Islam dan Kristen di Indonesia terbit di Bandung tahun 1969. 
f. Dibawah Naungan Risalah terbit di Jakarta 1971.

g. Ikhtaru, al-Khas Sabilani, Addi nu au La dinu yang diterbitkan di Jeddah tahun 1971.

h. Dakwah dan pembangunan diterbitkan di Bangil tahun 1974.

i. Dari Masa ke Masa yang diterbitkan pada tahun 1975 di Jakarta.

j. Buku Pendidikan Moral Pancasila dan Mutiara Hilang, sebuah buku yang mengkritik penyimpangan isi dari pelajaran PMP pada masa Orde Baru.

k. Mempersatukan Umat islam.

1. Dan lain-lain.

Disamping karya-karya dalam bentuk tulisan, Natsir juga memiliki jasa besar lewat berbagai kiprahnya. Diantara karya terbesar Natsir adalah Mosi Integral pada tanggal 3 april 1950 (Yusafrida, 2012:74). Saat itu bangsa Indonesia harus rela melepaskan kesatuannya menjadi negara serikat. Lewat Mosi Integral Natsir, bangsa Indonesia kembali bisa bersatu setelah dipecah belah oleh Belanda lewat "negara boneka". Atas jasa tersebut, tidak beberapa lama kemudian, Presiden Soekarno mengangkat Natsir menjadi Perdaan Menteri Pertama Indonesia. Pelantikan natsir sebagai perdana menteri merupakan hal yang wajar. Selain jasanya lewat Mosi Integral, Natsir juga menjabat sebagai ketua parta politik Islam, Masyumi. Dengan dilantiknya Natsir sebagai perdana menteri, dan terbentuknya kabinet baru, maka negara RIS bentukan Belanda pun bubar.

Atas jasa dan kontribusinya bagi Islam dan Indonesia, Natsir diberikan berbagai penghargaan tingkat Nasional dan Internasional (Sukri, 2019:87; Raihan, 2013:62). Pada tahun 1980, Natsir diberikan bintang penghargaan oleh pemerintah Tunisia dan Malik Faisal Price dari saudi Arabia. Sebelummnya, pada tahun 1967, Natsir meraih gelar Doktor Honoris Causa dari Universitas Lebanon, tahun 1991 dari Universitas Kebangsaan Malaysia dan Universitas Teknologi Malaysia. Presiden BJ Habibie pada 10 November 1998 menganugerahi Bintang Republik Indonesia kepadanya. Terakhir, pada 10 November 2008, Pemerintah RI menganugerahkan gelar Pahlawan Nasional kepadanya.

Natsir wafat di Jakarta pada tanggal 6 Februari 1993. Wafat pada usia 85 tahun, dua tahun setelah kematian istri tercinta dan dimakamkan di TPU Karet, Tanah Abang (Rajab, 2016:105, Raihan, 2013:62). Dalam umur yang singkat tersebut, Natsir telah melakukan berbagai gebrakan yang harus dicontohi oleh generasi setelahnya. Disamping menawarkan konsep pendidikan Islam, beliau juga berhasil menyatukan Indonesia lewat Mosi Integralnya.

\section{Kurikulum Pendidikan Islam menurut Muhammad Natsir}

Muhammad Natsir memandang pendidikan merupakan sesuatu yang sangat penting terkait kamajuan bangsa. Mustahil suatu bangsa akan merdekan tanpa terlebih dahulu maju. Pendidikan menjadi prasyarat sebuah bangsa maju. Mustahil suatu bangsa maju tanpa terlebih dahulu pendidikannya maju. Natsir pernah mengatakan: "Madju atau mundurnja salah satu kaum bergantung sebagian besar kepada peladjaran dan pendidikan yang berlaku dalam kalangan mereka itu. Tak ada satu bangsa jang terbelakang menjadi madju, melainkan sesudahnja mengadakan dan memperbaiki didikan anak-anak dan pemuda-pemuda mereka" (Natsir, 1973:142).

Dalam perjuangan Islam, peran pendidikan sangat signifikan. Natsir melihat pendidikan sebagai satu kesatuan dari kekuatan umat yang harus dijaga dan diberdayakan. Natsir pernah berpesan kepada jamaahnya, bahwa kekuatan umat Islam itu terdiri dari tiga komponen yang 
harus saling terkait, yaitu pesantren, mesjid, dan kampus. Ketiga komponen ini adalah basis kekuatan umat Islam yang harus dikembangkan secara sistematis (Ramayulis dan Nizar, 2009:382). Kekuatan ummat antara pesantren, mesjid, dan kampus harus diintegrasikan. Tidak boleh kekuatan tersebut dipisah-pisah. Apabila ketiga kekuatan tersebut dapat diintegrasikan, maka perjuangan Islam akan mudah terwujud.

Selanjutnya, perjuangan Islam melalui pendidikan akan tercapai akan tercapai jika selalu dilakukan pembaharuan dan perubahan. Pendidikan sebagai ajaran Islam memiliki sifat yang dinamis yang selalu menuntut perubahan. Perubahan dalam arti pembaharuan (tajdid) inilah yang membuat ajaran Islam itu benar-benar "shalih li kulli zaman wa makan". Oleh karena itu, pendidikan Islam secara umum, dan khususnya kurikulum selalu ada tuntutan zaman untuk dievaluasi serta dikembangkan sesuai perkembangan zaman.

Muhammad Natsir melihat kurikulum pendidikan Islam yang berlaku pada masanya terlalu banyak pelajaran dan hafalan. Peserta didik terlalu banyak dibebankan pelajaran. Disini Natsir melihat perlu dilakukan suatu evaluasi dan perubahan. Kurikulum harus sederhana dan tidak terlalu banyak mata pelajaran, akan tetapi lebih sistematis serta terarah. Sebab peserta didik memiliki latar belakang yang berbeda, mereka tidak akan sanggup menguasai mata pelajaran yang terlalu banyak.

Dalam pandangan Natsir, kurikulum harus lebih menjurus kepada potensi dan minat peserta didik, serta yang didukung dengan penguasaan bahasa yang baik. Jika pelajaran sesuai potensi dan minat sudah dikuasai, serta di dukung kemampuan bahasa yang memadai, selanjutnya peserta didik dapat mengembangkannya sendiri mereka sendiri (Natsir, 1973:142). Jadi peran guru dan sekolah tidak hanya mendidik saja. Lebih jauh dari itu, guru dan sekolah harus bisa mengembangkan bakat dan potensi yang dimiliki peserta didik.

Lebih mendalam lagi terkait kurikulum, Natsir melihat penyusunan dan pengembangan kurikulum harus dikembangkan secara integral. Penyusunan dan pengembangan yang wajib mempertimbangkan kebutuhan umum dan kebutuhan khusus sesuai dengan potensi yang dimiliki oleh peserta didik (Ramayulis dan Nizar, 2009:380). Selain itu, materi pendidikan tidak hanya terbatas pada bidang atau pelajaran keagamaan saja. Materi yang diajarkan harus mencakup pelajaran-pelajaran yang dianggap "umum", termasuk teknologi.

Natsir menolak adanya dikotomi materi pendidikan, antara materi yang dianggap umum dan agama. Dalam pandangan Natsir, sesuatu kekeliruan jika sekolah umum tidak diajarkan materi keagamaan. Begitu juga tatkala sekolah Islam tidak mau mengajarkan ilmu pengetahuan modern yang dianggap bukan bagain dari ajaran Islam. Oleh sebba itu, Natsir berusaha melakukan reformasi kurikulum pendidikan yang integral antara pelajaran yang dianggap umum dan agama. Dalam pandangan Natsir, agama atau dien mencakup seluruh tuntunan hidup hidup. Seseorang yang beragama Islam tidak mungkin saat belajar scient harus melepaskan diri dari Islam. Islam sebagai pedoman hidup mengatur semua urusan kehidupan manusia. Ilmu pengetahuan tidak mungkin dipisahkan dari ajaran agama. Agama dan ilmu pengetahuan harus berjalan dengan selaras. Jika kedua hal tersebut dipisahkan, maka akan muncul para intelektuan yang tidak beragama, atau agamawan yang tidak memiliki pengetahuan (Ahmad, 1995:34).

Pendidikan yang dikotomi bukanlah cara pandang Islam. Pendidikan dikotomi lebih mirip dengan cara pandang sekuler. Hal ini tentu sangat bertolak belakang dari ajaran Alquran. Alquran mengajarkan sesuatu secara selaras antara dunia dan akhirat. Manusia tidak hanya 
diperintahkan untuk mencari kebaikan untuk akhirat, tapi juga kebaikan untuk dunia. Allah berfirman:

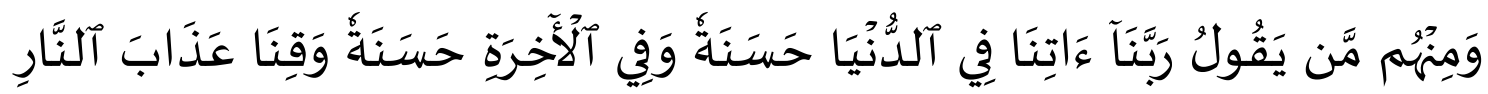

Artinya: "Dan di antara mereka ada orang yang berdoa, "Ya Tuhan kami, berilah kami kebaikan di dunia dan kebaikan di akhirat, dan lindungilah kami dari azab neraka." (Al-Baqarah: 201).

Atas dasar itu, Natsir tidak sepakat dengan sistem pendidikan sekuler yang memisahkan agama dari dunia. Oleh sebab itu, pada Juni 1938, Natsir memberi kritikan keras atas sebuah pemikiran yang ingin mendirikan tiga perguruan tinggi di tiga kota, Jakarta, Solo, dan Surabaya. Perguruan tinggi dalam bidang ilmu umum tanpa pelajaran agama akan didirikan di Jakarta. Perguruan tinggi ini akan diprioritaskan untuk alumni HBS dan AMS. Untuk lulusan madrasah atau sekolah Islam kurang diberi kesempatan di perguruan tinggi ini. Selanjutnya di Solo akan didirikan sekolah tinggi untuk mendidik para calon ulama. Mahasiswa di perguruan tinggi di Solo ini akan diberi pelajaran agama yang cukup, namun tidak ada pelajaran umum. Sedangkan di Surabaya akan dibangun sekolah tinggi untuk para alumni pesantren.

Gagasan pendirian sekolah diatas menerapkan kurikulum yang dikotomi. Gagasan ini ditentang keras oleh Natsir. Menurut Natsir, gagasan ini sangat berbahaya. Jika perguruan tinggui umum tidak diajarkan agama, atau perguruan tinggi agama tidak diajarkan pengetahuan umum, akan melahirkan para intelektual yang menentang Islam dan dan kelompok yang berpandangan kebarat-baratan (Natsir, 1973:90). Natsir tidak pernah mempersoalkan pendidikan yang datang dari barat atau timur, namun yang dipersoalkan oleh Natsir adalah paham sekularisme sebagai sebuah paham yang "netral agama" (la diniyah) (Ulumuddin, 2016: 286).

Dalam pandangan Natsir, kebahagian yang harus diraih tidak hanya terbatas pada kebahagiaan di akhirat, tapi juga didunia. Kebahagiaan dunia dan akhirat tidak dapat diraih hanya dengan menguasai pengetahuan agama saja. Tetapi juga harus menguasai ilmu umum serta teknologi sebagai perangkat untuk mengemban ajaran allah. Makanya Natsir memadukan pendidikan umum dan agama secara integral disekolah yang didirikannya, yaitu Pendis. Gamal Abdul Nasir Zakaria pernah mengungkapkan: "Beliau ingin membuktikan kepada Belanda dan masyarakat bahwa pendidikan dan perguruan Islam mampu bersaing dengan pendidikan konvensional lainnya dalam mencetak oupt yang berkualitas" (Parydharizal, tt:47).

Konsep dasar kurikulum yang dikembangkan oleh Natsir merupakan suatu konsep pendidikan yang integral, universal, dan harmonis. Konsep pendidikan yang integral adalah pendidikan yang tidak mengenal dikotomi antara urusan dunia dan agama. Oleh karena itu, pengembangan kurikulum mesti sesuai dengan misi tersebut. Sebuah kurikulum yang berisi ilmu-ilmu agama Islam dan juga pengetahuan umum. Semua ilmu dunia dan akhirat dijadikan sebagai satu kesatuan pengetahuan yang tak dapat dipisahkan karena sama-sama berasal dari Allah (Nata, 2005: 88).

Sebaliknya, cara pandang dikotomi antara pendidikan agama dan umum merupakan cara pandang kaum sekuler. Natsir menentang keras ide-ide sekulerisasi pendidikan melalui dikotomi pendidikan Islam dan Umum. Dikotomi ilmu agama dan ilmu umum adalah teori yang lahir dari pemikiran sekuler. Ide ini sangat bertentangan dengan ajaran Islam. Konsep Alquran tentang manusia sangat jelas, manusia adalah makhluk yang memiliki unsur jasmani dan rohani, fisik dan jiwa. Kedua unsur tersebut membutuhkan pendidikan yang tidak dapat dipisah-pisah. Dan 
manusia tidak bisa menjalankan tugasnya sebagai khalifah di muka bumi kecuali dengan penguasaan yang baik terhadap kedua ilmu ini. Allah berfirman:

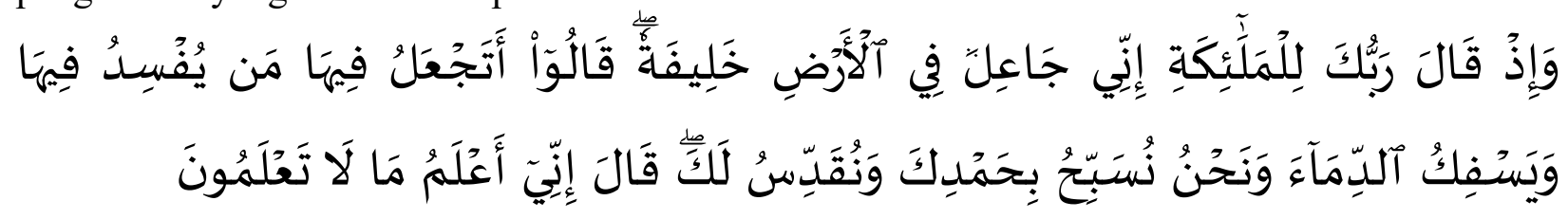

Artinya: "Dan (ingatlah) ketika Tuhanmu berfirman kepada para malaikat, "Aku hendak menjadikan khalīfah di bumi." Mereka berkata, "Apakah Engkau hendak menjadikan orang yang merusak dan menumpahkan darah di sana, sedangkan kami bertasbih memuji-Mu dan menyucikan nama-Mu?" Dia berfirman, "Sungguh Aku mengetahui apa yang tidak kamu ketahui." (Al-Baqarah :Ayat 30).

Hal diatas sesuai dengan hakikat pendidikat dalam pandangan Natsir yang mengcakup jasmani rohani. Bahkan, pendidikan merupakan suatu pimpinan jasmani dan rohani yang membawa kepada kesempurnaan dan lengkapnya sifat-sifat kemanusiaan dalam arti sesungguhnya. Pimpinan dalam kontek ini mengandung dua unsur, yaitu satu tujuan dan satu asas. Satu tujuan untuk mengarahkan proses pendidikan, sedangkan satu asas sebagai dasar atau landasan (Natsir, 1973:82).

Pendidikan integral yang dikembangkan Natsir harus berlandaskan tauhid. Tauhid, bagi Natsir, harus dijadikan sebagai pijakan bagi seorang muslim dalam segala hal, termasuk pendidikan. Bahkan, tauhid harus diberikan sedini mungkin selagi masih muda dan mudah dibentuk sebelum didahului oleh berbagai ideologi lainnya. Hal ini didasari dari tujuan pendidikan itu sendiri. Dalam pandangan Natsir, tujuan pendidikan tidak dapat dipisahkan dari tujuan hidup manusia itu sendiri, yaitu " memperhambakan diri kepada Allah", atau dalam istilah lain mengtauhidkan Allah. Inilah tujuan hidup manusia didunia ini. Oleh sebab itu, tujuan pendidikan inilah yang harus menjadi substansi utama kurikulum pendidikan Islam serta diberikan kepada peserta didik sebagai bekal menghadapi kehidupan ini (Natsir, 1973:82, Ulumuddin, 2016: 288; Suwarno, 2017:99).

Ide menjadikan tauhid sebagai dasar pendidikan dikemukakan Natsir pertama kali dalam rapat Persatuan Islam (PERSIS) di Bogor pada tanggal 17 Juni 1934. Dalam rapat tersebut, Natsir memaparkan makalah yang berjudul "Ideologi Didikan Islam". Dalam makalah tersebut, Natsir menceritakan kisah bunuh diri seorang ahli fisika yang bernama Prof. Paul Ehrenfest. Bunuh diri yang dilakukan setelah membunuh anak tunggalnya. Kejadian yang sangat disayangkan ini, menurut Natsir, disebabkan kehilangan tempat bergantung. Dalam surat yang dikirimkan ke sahabat karibnya yang bernama Prof.Kohnstamn, Prof Paul Ehrenfest membunuh anaknya didasari rasa kecewa atas potensi yang dimiliki anak tunggalnya tidak sesuai harapan, padahal sudah didik secara ektra (Natsir, 1973:82). Oleh sebab itu, Natsir melihat pendidikan Islam tidak dapat dipisahkan dari tauhid sebagai ideologi dan orientasi pendidikan seorang muslim. Orang-orang yang kehilangan orientasi akan berada pada posisi anti agama yang berakhir kekacauan dilubuk hatinya (Natsir, 1973:142).

Pandangan Natsir diatas mengacu kepada firman Allah pada surat Adz-Dzariyat ayat 56:

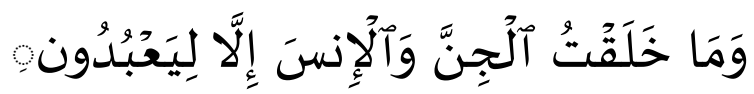


Artinya: "Aku tidak menciptakan jin dan manusia melainkan agar mereka beribadah kepada$K u$ " (Adz-Dzariyat: 56).

Menurut Natsir, istilah menyembah-Ku yang terdapat dalam ayat diatas memiliki makna yang luas dan dalam (Natsir, 1973:82). Konsep menyembah atau tauhid dalam ayat diatas meliputi semua ketaatan dan ketundukan pada perintah ilahi yang membawa kepada kebesaran di dunia dan kemenangan diakhirat. Dan menjauhkan diri dari dari semua larangan ilahi agar tercapainya kemengan di dunia dan akhirat. Ketundukan dan ketaatan dalam perintah dan larangan ilahi tidak hanya dibatasi pada wilayah privat (hablum minallah). Namun, ketundukan dan ketaatan ini juga memasuki wilayah sosial kemasyarakatan (hablum minallah).

\section{KESIMPULAN}

Reformasi kurikulum yang integral ini merupakan hasil ijtihad dari Al-Qur'an dan AsSunnah sebagai jawaban atas kondisi pendidikan yang dikotomi saat itu. Kurikulum pendidikan Islam menurut Muhammad Natsir harus disusun dan dikembangkan secara integral. Tidak boleh adanya dikotomi kurikulum pendidikan Islam antara pelajaran umum dan pelajaran agama. Pandangan dikhotomi pendidikan umum dan agama lahir dari pemikiran sekuler. Pandangan ini sangat bertentangan dengan pandangan Islam yang integral melihat dunia akhirat, atau badan dan ruh. Hal ini sesuai dengan tujuan hidup seorang muslim, bahagia didunia dan akhirat.

Selanjutnya, penyusunan dan pengembangan yang wajib mempertimbangkan kebutuhan umum dan kebutuhan khusus sesuai potensi yang dimiliki peserta didik serta kemapuan bahasa yang cukup. Apabila pelajaran yang diberikan sesuai potensi dan minat sudah dikuasai, serta di dukung kemampuan bahasa yang memadai, selanjutnya peserta didik dapat mengembangkannya sendiri mereka sendiri. Jadi peran guru dan sekolah tidak hanya mendidik saja. Lebih jauh dari itu, guru dan sekolah harus bisa mengembangkan bakat dan potensi yang dimiliki peserta didik. Dan, pengembangan kurikulum harus berlandaskan tauhid sebagai pijakan bagi seorang muslim dalam segala hal.

\section{DAFTAR PUSTAKA}

Ahmad, Amrullah. Pendidikan Dalam Perspektif Epistemologi Islam. Jakarta: Media Dakwah, no. 251, Mei 1995.

Ansyar, Mohammad. (2015). Kurikulu: hakikat, fondasi, desain, dan pengembangan. Jakarta: Kencana Prenadamedia Group.

Al-Asy'ari, M.Khoirul Hadi. (2014). Dakwah Tranformatif Muhamamd Natsir. Jurnal Walisongo Vol. 22, No.2.

Falah, Saiful. (2015). Pendidikan Kepemimpinan M.Natsir dan Implementasinya di Lembaga Pendidikan. Edukasi Islami: Jurnal Pendidikan Islam Vol. 4, No.8.

Hamalik, Oemar. (2009). Dasar-Dasar Pengembangan Kurikulum. Cet.Ke-2. Bandung: PT. Remaja Rosdakarya.

Harahap, Syahrin. (2011). Metodologi Studi Tokoh Pemikiran Islam. Jakarta: $\quad$ Prenada.

Harjono, Anwar dkk. (1996). Pemikiran dan Perjuangan Muhammad Natsir. Jakarta: Pustaka Firdausi.

Harahap, N. (2014). Penelitian Kepustakaan. Jurnal Iqra' Vol. 08, No. 01. 
Khatibah. (2011). Penelitian Kepustakaan. Jurnal Iqra' Vol.05, no.01.

M. Federspiel, Howard. (1996). Persatuan Islam: Pembaharuan Islam Indonesia Abad XX, terj. Yudian W.Asmin dan Affandi moctar. Yogyakarta: UGM Press.

Nata, Abudin. (2005). Tokoh-tokoh Pembaharuan Pendidikan Islam di Indonesia. Jakarta: PT. Raja Grafindo Persada.

Nata, Abudin. (1999). Filsafat Pendidikan Islam. Jakarta: Logos Wacana Ilmu

Nizar, Syamsul dan Ramayulis. (2011). Filsafat Pendidikan Islam: telaah system pendidikan dan pemikiran para tokoh. Cet. Ke-3. Jakarta: Kalam Mulia.

Natsir, M. (1973). Capita Selecta 1. Jakarta: Bulan Bintang.

Nazir, M. (1985). Metode Penelitian. Jakarta: Ghalia Indonesia.

Pratikya, A.W (Ed). (1989). M. Natsir, Pesan Perjuangan seorang Bapak. Cet.ke-1. Jakarta : DDII.

Parydharizal, Ganna. Konsep Pendidikan M. Natsir "Mendidik Ummat dengan tauhid. (Majalah Sabili, Edisi Khusus 100 tahun Muhammad Natsir).

Rajab, La. (2016). Konsep pendidikan Islam muhammad Natsir (Suatu Kajian Analisis Kritis). Al-Iltizam: Jurnal Pendidikan Agama Islam Vol.1, No.1.

Raihan. (2013). Kepemimpinan Muhammad Natsir di Dewan Da'wah Islamiyah Indonesia (1067-1993). Jurnal AL-Bayan: Media kajian dan Pengembanagn Ilmu Dakwah Vol.19, No.2.

Ramayulis. (2013). Ilmu Pendidikan Islam. Cet. Ke-10. Jakarta: Kalam Mulia.

Roziqin, Badiatul. d.k.k. (2009). 101 Jejak Tokoh Islam Indonesia, Yogyakarta:e-Nusantara.

Suriasumantri, J. (1998). Penelitian Ilmiah, Kefilsafatan, dan Keagamaan: Mencari Paradigma Kebersamaan. In D. \&. Ridwan, Tradisi Baru Penelitian Agama Islam: Tinjauan Antardisiplin Ilmu (p. 41). Bandung: Nuansa.

Sumanto, Edi (2016). Relevansi Pemikiran Demokrasi Abu 'Ala Al-Maududi dengan Muhammad Natsir. El-Afkar Vol.5, No.1.

Suwarno. (2017). Pemikiran M.Natsir dalam pembaharuan Pendidikan Islam di Indonesia. DAR EL-ILMI: Jurnal Studi Keagamaan, pendidikan, dan Humaniora Vol. 4, No. 1.

Syam, Firdaus. (2004). Yusril Ihza Mahendra; Perjalanan Hidup, Pemikiran dan Tindakan Politiknya. Jakarta: PT. Dyatama Milenia.

Syaodih Sukmadinata, Nana. (2017). Pengembangan Kurikulum Teori dan Praktik. Bandung: remaja Rosda Karya.

Sukri, Mhd Alfahjri. (2019). Islam dan Pancasila dalam Pemikiran Mohammad Natsir. ALFUAD: jurnal Ilmiah Sosial Keagamaan Vol.3, no.1.

Tafsir, Ahmad. (2014). Ilmu Pendidikan dalam Perspektif Islam. Cet. Ke-11. Bandung: PT. Remaja Rosdakarya.

Tholkhah, Imam dan Ahmad Barizi. (2004). Membuka Jendela Pendidikan "Mengurai Akar Tradisi dan integrasi keilmuan Pendi dikan Islam”. Jakarta: PT. Raja Grafindo Persada. 
Ulumuddin, Ihya. (2016). Demokrasi Pendidikan Islam Perspektif Muhammad Natsir dan Relevansinya dengan Sistem Pendidikan Nasional. Maraji': Jurnal Ilmu Keislaman Vol.2, No. 2.

Windi. A. (2007). 100 Tokoh yang Mengubah Indonesia. Jakarta: PT. Buku Kita.

Yusafrida. (2012). Kiprah Politik Muhammad Natsir. Jurnal TAPIs Vol.8, No.2. 